\title{
KIFÜ nemzetközi együttműködései és projektjei
}

\author{
Mohácsi János \\ ORCID: 0000-0002-1847-4437 \\ KIFÜ, nemzetközi kapcsolatokért felelös vezető \\ mohacsi.janos@kifu.gov.hu
}

\begin{abstract}
The professional work under the NIIF Program has been a key enabler for Hungarian research and education since 1986.The KIFÜ's infrastructure is part of the GÉANT (European ICT Infrastructure) and EuroHPC and PRACE (European Supercomputing Infrastructure) infrastructures, multimedia information management, resource and service virtualization, federated authentication, etc. ensure effective and full connectivity with all European research institutions and researchers, including all European research infrastructures (ESFRI, ERIC and others). This paper presents the international cooperation and projects of the KIFÜ and the NIIF Program.
\end{abstract}

Keywords: infrastructures, networking, computing, NREN

\section{Bevezetés}

Az NIIF (korábban IIF) Program keretében folyó országos jelentőségű szakmai munka 1986 óta meghatározó kiszolgálója a hazai kutatásnak és oktatásnak, de egyúttal jelentős speciális szegmense a magyarországi informatikának is. Ez a munka, amely a 90-es évek eleje óta nemzetközi együttműködésben a nemzetközi élvonallal együtt haladva végez az I²F, majd NIIF közösség. Nemzetközi szinten is jellemzően a kutatói hálózatokra épülő e-Infrastruktúrák ${ }^{1}$ világszerte virágzanak, fejlesztésük és használatuk egyre intenzívebb és szélesebb körű (kutatásbázisú innováció, ipari együttműködések, nyitott tudomány, adat-infrastruktúrák, szuper-számítástechnika, virtuális környezetek és szervezetek, globális kollaboráció stb.). Az e-infrastruktúrák horizontális módon biztosítanak adatmozgatási, adathozzáférési, adatfeldolgozási és egyéb együttmúködést támogató szolgáltatásokat minden diszciplináris kutatásnak, tudományos projekteknek beleértve Európa valamennyi (ESFRI, ERIC és egyéb) kutatási infrastruktúráját is.

1 https://ec.europa.eu/digital-single-market/en/e-infrastructures 


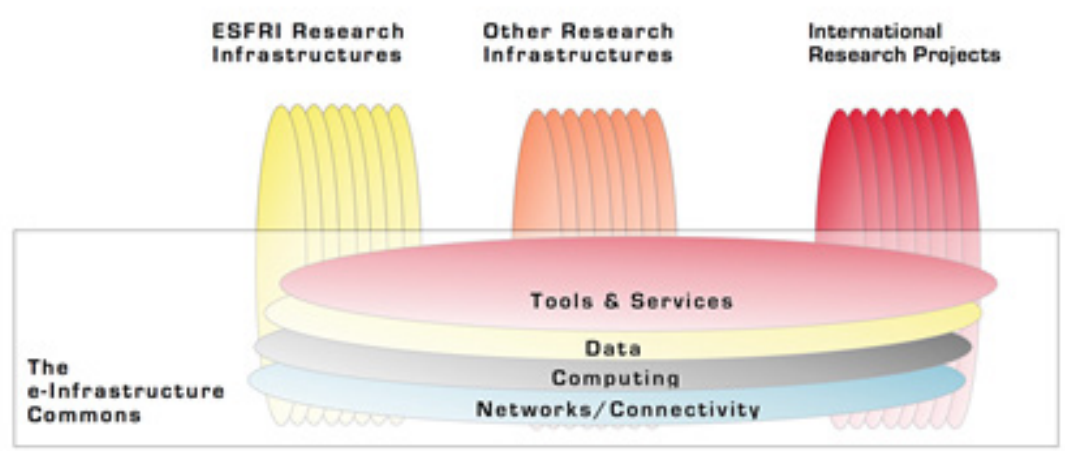

1. ábra: e-infrastruktúrák viszonya az EC e-IRG tanácsadó testület szerint

Az elmúlt 35 év forradalmi új szakaszt indított be és alapozott meg a tudományos kutatás technológiája, metodikája és innovációs hatása, ezen keresztül a gazdasági versenyképességre és a társadalmi jólétre gyakorolt hatása tekintetében.

\section{A KIFÜ nemzetközi együttműködései}

A kutatás-oktatás-közgyűjtemények magyarországi IKT infrastruktúrája (az utóbbi években szokásossá vált európai szóhasználattal e-infrastruktúrája vagy digitális infrastruktúrája) szempontjából a nemzetközi kapcsolatoknak továbbra is kiemelkedő a jelentőségük. A kapcsolatokat három jellemző alapján értékelhetjük:

1. a külföldi partnereinkkel együttműködésben üzemeltetett szolgáltatások,

2. a fejlesztési irányok tekintetében meghatározó jelentőségű szervezeti együttműködések,

3. a nemzetközi együttmüködésben megvalósított projektek.

E három láb elsősorban személyes és elektronikus információcsere keretében támogatja kapcsolatainkat. 2020 év elején Magyarországon és Európában is megjelent a COVID-19 vírus, így a személyes kapcsolattartással szemben az elektronikus kapcsolattartás (videokonferencia, e-mail, különböző webes technológiák) vált meghatározóvá.

A program nemzetközi együttmüködése stabil maradt és az oktatás, kutatás és közgyűjteményeknek nyújtott szolgáltatások fenntarthatósága szempontjából pedig jól működtek. A COVID-19 járvány által okozott jelenlegi helyzet mindannyiunk számára példátlan, a mindennapi élet európai és globális szintű megzavarásával szembesülünk. 2020-ban kihívásokkal teli időkben a GÉANT munkatársai, partnerei és az NREN közösség tagjai- köztük a KIFÜ összefogtak, hogy hasznos információkat és forrásokat gyűjtsenek és osszanak meg, biztosítsák az oktatás és kutatás számára alapnak tekintett szolgáltatások biztonságos nyújtását, és olyan gyorsan új javaslatokat dolgozzanak ki, amelyek támogatják kutatási és oktatási közösségünket a pandémiás válságban² .

\section{2 https://www.geant.org/People/COVID-19_Community_Support}


A HUNGARNET és a KIFÜ együttműködése hozzájárult a felhasználók és a fejlesztésszolgáltatás szempontjait is érvényesítő kapcsolatrendszerünk stabilitásához, ezen kapcsolatrendszerünknek is köszönhető, hogy sikerült továbbra is megtartani a nemzetközi együttműködések szempontjából is meghatározó jelentőségű integráltságot.

Az integráltság különösen fontos a kutatás és oktatás hazai e-infrastruktúrájának feltételrendszere, szolgáltatási spektruma és főként alkalmazói-alkalmazási teljessége terén. Mindez - a 2016-ban kialakult helyzetből adódóan - 2020-ban is túlnyomórészt a KIFÜ ernyője alatt valósult meg, kapcsolódva a HUNGARNET által is képviselt felhasználói érdekekhez-szempontokhoz, de jó kapcsolatokat ápolva a kutatás számára az e-infrastruktúrába illeszkedő szolgáltatásokat nyújtó KIFÜ-n kívüli partnerekkel is, mint például a OpenAire ${ }^{3}$ és egyéb adatrepozitóriumok.

Az oly fontos integráltság, mely szerencsés módon az elmúlt évben is Európa-szerte irigyelt ritka előnye és stabilitási tényezője maradt az NIIF Program céljaihoz illeszkedően működtetett itthoni e-Infrastruktúrának, jelentős mértékben hozzájárult nem csak ahhoz, hogy a szolgáltatások gyakorlatilag "one stop shopping" elvet követően legyenek elérhetők, hanem valóban, maguknak a nemzetközi kapcsolatoknak a fenntartásáhozfenntarthatóságához is. Itt érdemes megjegyezni, hogy egyre jellemzőbbé kezd válni, az e-infrastruktúrák összekapcsolódása, illetve egyre szorosabb együttműködése. Az előbb leírt helyzetet kell továbbra is fenntartanunk, a korábbiakhoz hasonló tudatos építkezés útján, az infrastruktúra fejlesztése és alkalmazása, valamint a szolgáltatások nyújtása terén is, maximálisan kihasználva - mind az üzemeltetői, mind pedig a felhasználói oldalon - a benne rejlő lehetőségeket.

Igen kedvező alapot jelentett 2020-ban is az említett kedvező helyzet fenntartása szempontjából, hogy a nemzetközi kapcsolatok "három lábon álló" stabil működésében továbbra is többé-kevésbé egyenlő súlyú, kiegyensúlyozott szerepet játszott a projektkapcsolatok, a szervezeti kapcsolatok, valamint a (hálózati és egyéb) szolgáltatási kapcsolatok hármas egysége.

\section{A KIFÜ nemzetközi projekt részvételei}

Ahogy korábban, a projekt kapcsolatokat tekintve 2020-ban is kulcsfontosságú volt nemzetközi együttmúködéseink szempontjából az EU Horizon2020 programja keretében futó GÉANT és PRACE "zászlóshajó" projektekben való KIFÜ részvétel és ezeken keresztül kapcsolódásunk Európa kutatói hálózati és HPC tárgyú együttmúködéseinek az élvonalához. Emellett megjelent a Nyílt Tudomány támogatása is mely több projektben, több különböző résztvevővel valósult meg (Ni4OS-Europe - Debreceni Egyetem, KIFÜ; OCRE- KIFÜ GÉANT kedvezményezettként; OpenAIRE- Debreceni Egyetem; ExPaNDS - SZTAKI EGI alvállalkozójaként, EOSC-Future - KIFÜ alvállalkozóként). 

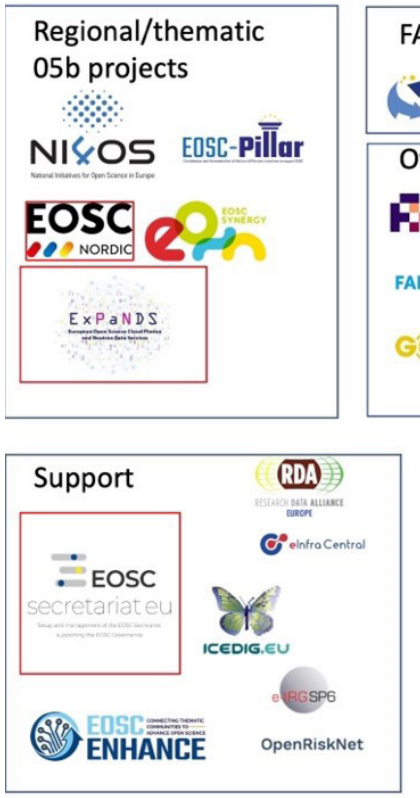
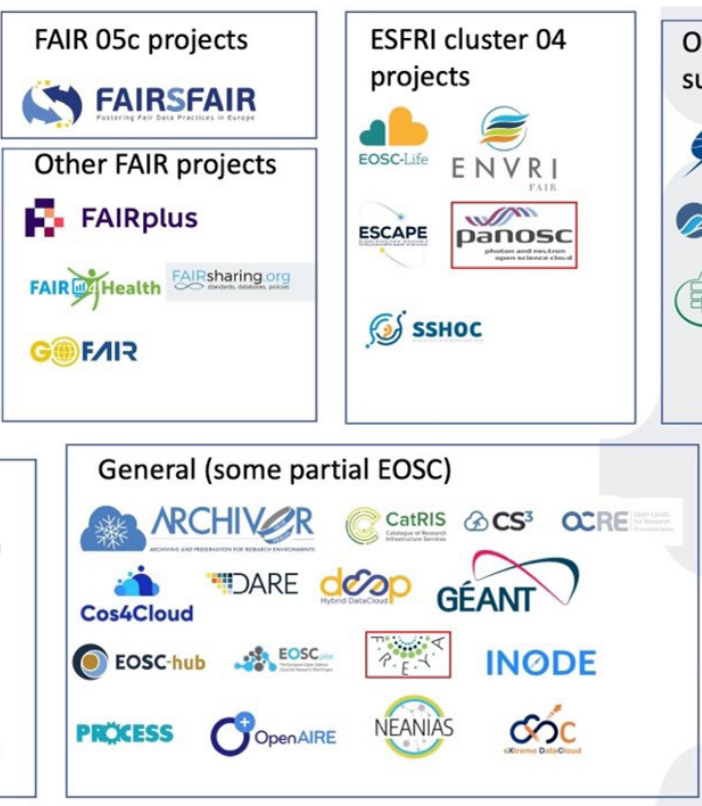

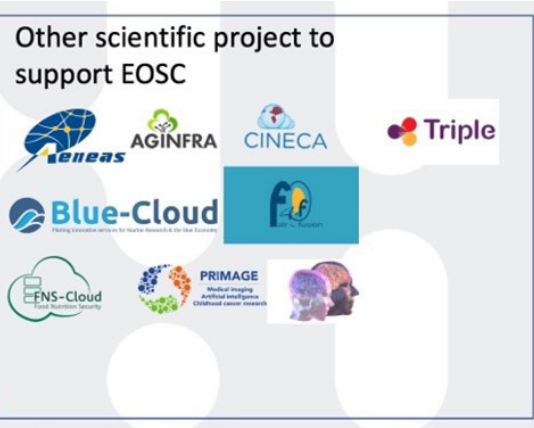

Other Data

economy

Health
Europe $\mathrm{M}$

Forrás: https://www.eoscportal.eu/about/eosc-projects

2. ábra: EC támogatású Nyílt Tudományosságot támogató projektek

2019-ben elindultak a 2022-ig tartó GN4-34 és GN4-3N projektek, melyek többek között a gerinchálózat új generációjának a kiépítését túzték ki célul. Mindez lehetővé teszi olcsóbb, illetve NREN-ekre épülő megoldások (Spectrum Connection Service, Whitebox router, $\mathrm{DCl}$ ) alkalmazását. A finanszírozást tekintve viszont kedvező, hogy ez a projekt is az európai NREN-ek közössége és az EC által aláírt FPA (Framework Partnership Agreement, azaz együttműködési keretmegállapodás) feltételrendszerének megfelelően múködik. A GN4-3 és a GN4-3N projekt hagyományos célja, hogy a lehető legmodernebb és költséghatékonyabb hálózati technológiák alkalmazásával a legfejlettebb adathálózati szolgáltatásokat lehessen kialakítani Európában.

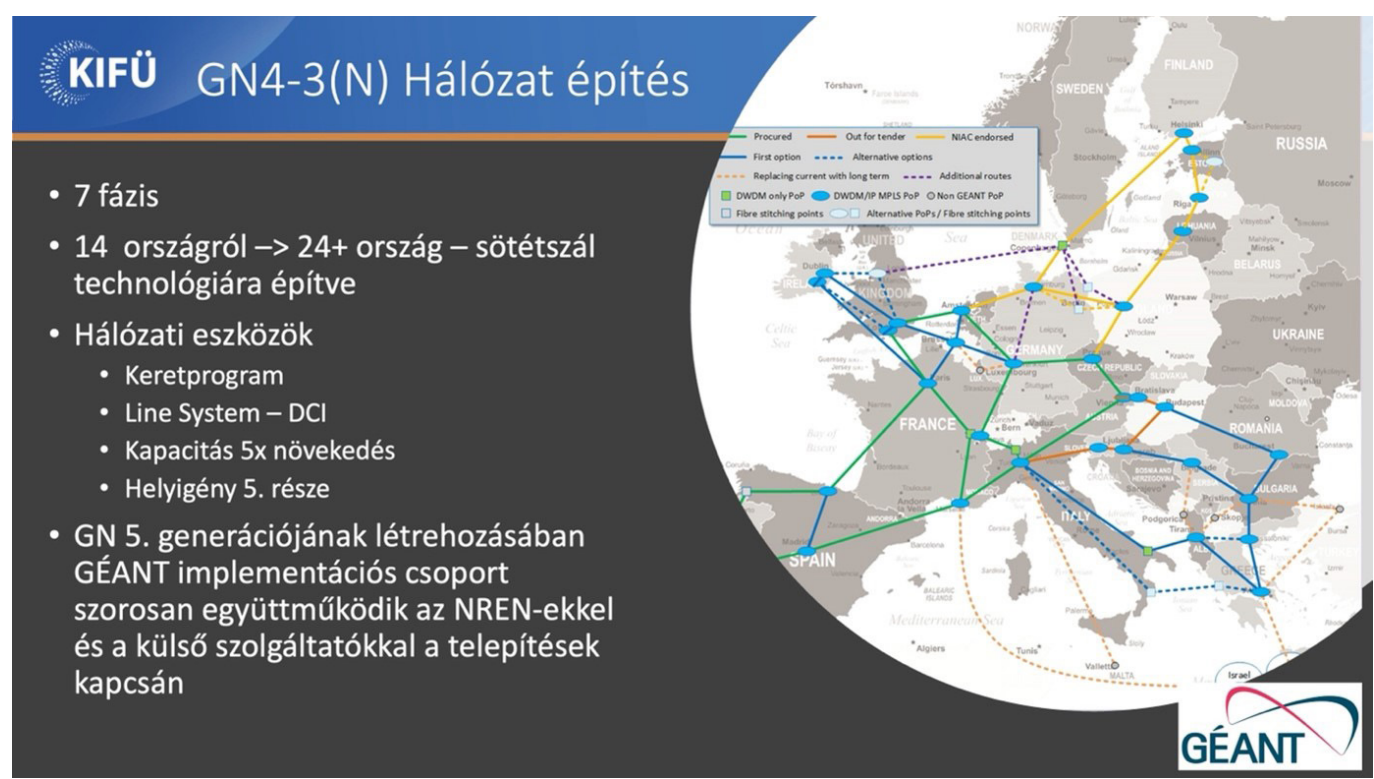

3.ábra: GN4-3(N) hálózat építés

4 https://www.geant.org/Projects/GEANT_Project_GN4-3 
A GN4-3 egyébként folytatta a hagyományos GÉANT szolgáltatások mellett a 2018-ben beindított cloud-infrastruktúra szolgáltatást is, mely a legfontosabb kereskedelmi felhőés storage-szolgáltatókkal kötött speciális megállapodások keretében, kedvezményes feltételek között érhető el az NREN-eken keresztül az európai kutatási és oktatási közösségek számára. Magyar részről a KIFÜ keretében folytatódott a hazai fejlesztésű oktatási felhő szolgáltatás és a GÉANT szolgáltatás közötti együttműködés minél kedvezőbb (minden tekintetben kölcsönösen előnyös) kidolgozására irányuló munka. A GÉANT fejlesztések kapcsán kiemelendők a T\&l (Trust and Identity) fejlesztések, különös tekintettel az eduGAIN-re és eduTEAMS-re, valamint a rendkívül erős multimédia szolgáltatás-fejlesztés, és a white-box routereket támogató freertr portolás, hiszen magyar részről ezek keretében szintén jelentős hozzájárulások voltak a projektben.

Érdemes külön kiemelni az edumee ${ }^{5}$ fejlesztést, amely egy nyílt forrású videokonferencia rendszer, amely hozzájárult a COVID-19 időszakban sok oktatási és kutatási intézményben ahhoz, hogy tovább folytatódhasson a munka.

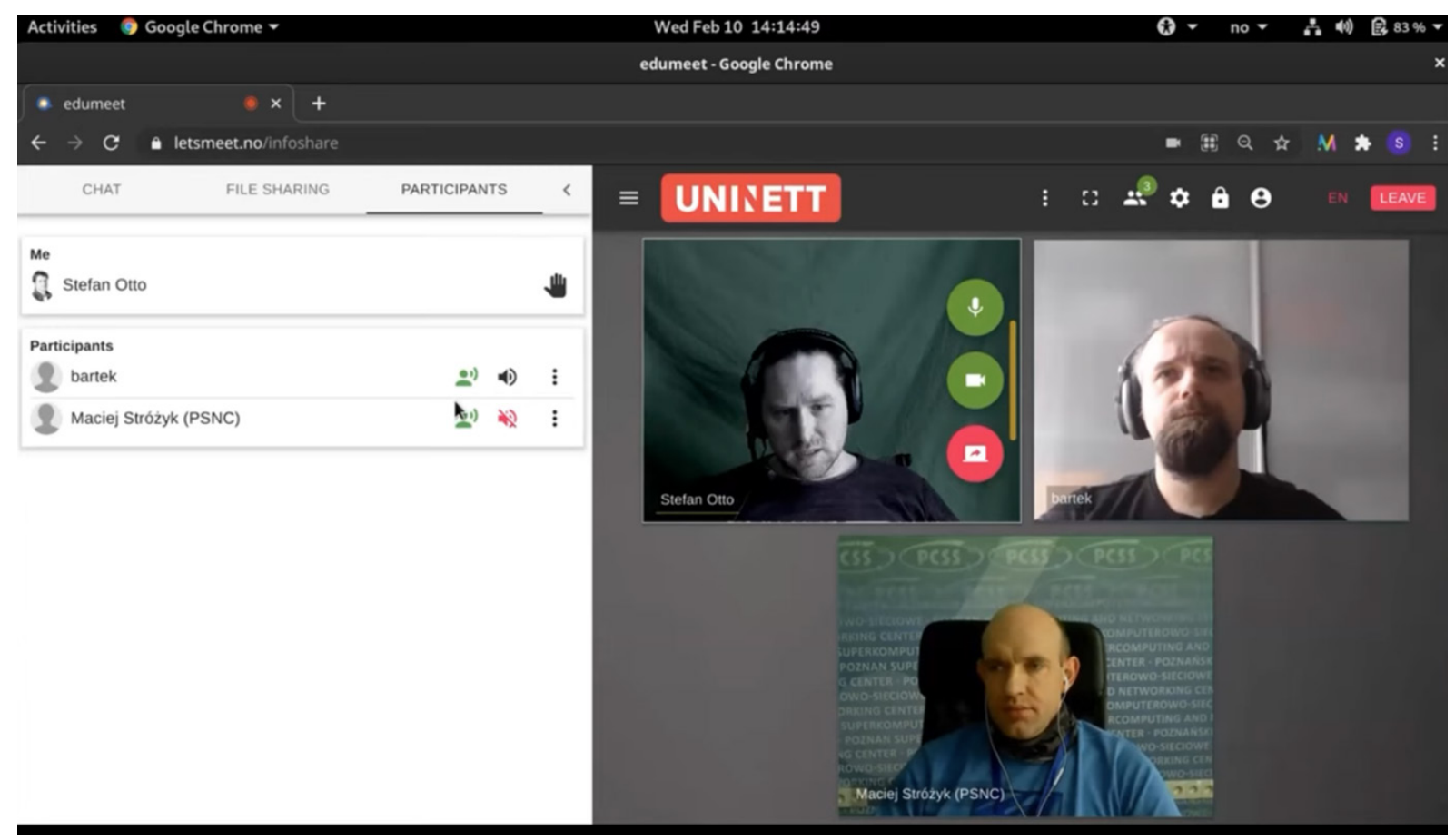

4.ábra: edumeet felhasználói felület

A PRACE mellett egyre meghatározóbb az EuroHPC együttműködésben való koordinációs-kooperációs kapcsolódás. A korábbi évek NIIF Intézeti és később KIFÜ erőfeszítéseinek eredményeként a HPC terület NKFIH támogatási ígérvényt kapott, mely lehetővé tette az EuroHPC csatlakozóknak- köztük Magyarországnak- a nemzetközi pályázást. Magyarországon a KIFÜ vezetésével HPC kompetencia központ jött létre, 2020 nyarától kezdve. Ennek a hazai munkának a nemzetközi koordinációját biztosítja a 2020 szeptemberétől múködő EuroCC projekt. A PRACE2 Együttműködési Program (Partnership for Advanced Computing in Europe) 2020-ben megfelelő alapot biztosított a GÉANT-hoz hasonlóan magas prioritású részvételhez a PRACE együttmúködésben,

5 https://edumeet.org/ 
ezzel kiváló HPC környezetet biztosítva a magyar e-Infrastruktúra fejlesztő és múködtető, valamint alkalmazó közösségnek. 2020-ban folytatódott a PRACE-6IP' projekt, mely európai szuperszámítógép központok együttmúködésének fokozását tǔzte ki célul.

AGÉANT-ra épülő európai hálózati kapcsolatokés az ezekre támaszkodó e-Infrastruktúra szolgáltatások (cloud, HPC, VolP, VC, WebRTC, data) terén - bár lényeges változásra a szolgáltatásokban általában nem került sor - a nemzetközi kapcsolatok tovább gazdagodtak, szélesedtek és mélyültek, de legalábbis szinten maradtak, ezáltal kedvező módon bővültek az együttműködési lehetőségek. E lehetőségek kiaknázására a KIFÜben az elkövetkezőkben is komoly figyelmet kell fordítani.

A 2020-as év során folytatódtak a munkák az adat-infrastruktúrák és az infrastruktúra globalizáció terén. A 2019 szeptemberében elindult új Horizon2020 projekt, a NI4OS-Europe ${ }^{7}$, melynek célja, hogy az Open-Science együttmúködéseket erősítse a Nyugat-Balkántól egészen Kelet-Európáig, folytatódott.

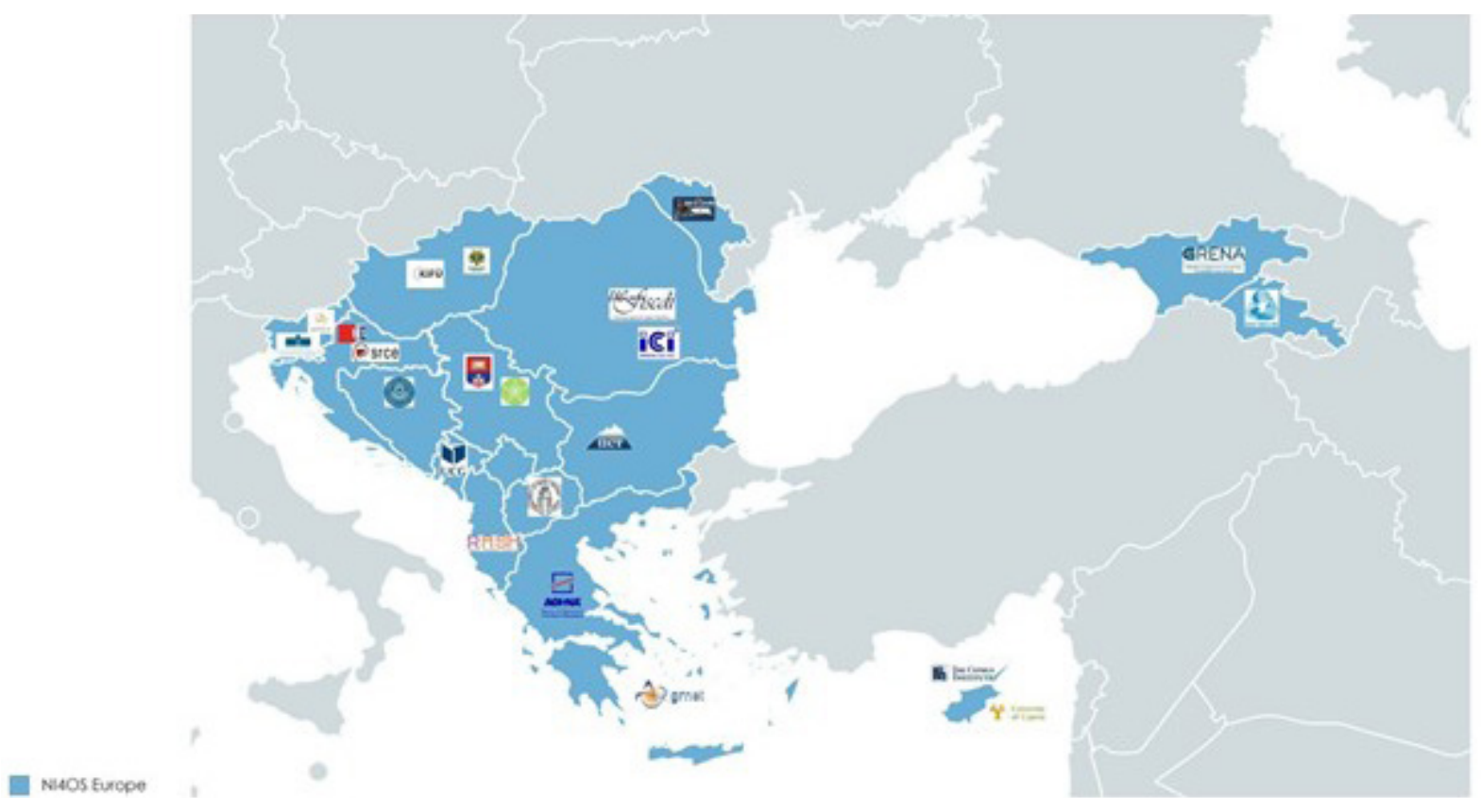

5.ábra: NI4OS-Europe partnerek

Ennek a projektnek a fó célkitúzése a helyi nemzeti és regionális lehetőségek kiaknázása mellett, az Open Science irányelvek kialakítása, az EOSC - Európai Nyílt Tudományos Együttmúködés szolgáltatásaihoz (on-boarding) történő csatlakozás támogatása, a FAIR - Findability, Accessibility, Interoperability and Reusability (megtalálható, hozzáférhető, szabványosak és újrafelhasználható) adatkezelési alapelvek adaptálásának megkönnyítése, valamint konzultációk, tréningek szervezése az érintett csoportok számára. Ezt egészíti a 2021 áprilisában indult EOSC-Future project, melynek az a célja, hogy múködő integráló EOSC platformot („Rendszerek szövetsége”) hozzon létre, amely adatokból, szakirányú tudományos szolgáltatásokból, valamint nyitott kutatási termékekból és infrastruktúrából

\footnotetext{
6 https://prace-ri.eu/

7 https://ni4os.eu/
} 
áll, amelyekhez a résztvevő Európai kutatók támogatást és képzést kapnak az EOSC erőforrásainak és megoldásainak felhasználásához.

\section{KIFÜ Tudományos klaszterek támogatása}

ESFRI Science Clusters :

- ENVRI-FAIR - environmental sciences

- EOSC-Life - life sciences

- ESCAPE - astronomy and particle physics

- PaNOSC - photon and neutron sciences

- SSHOC - social sciences and humanities

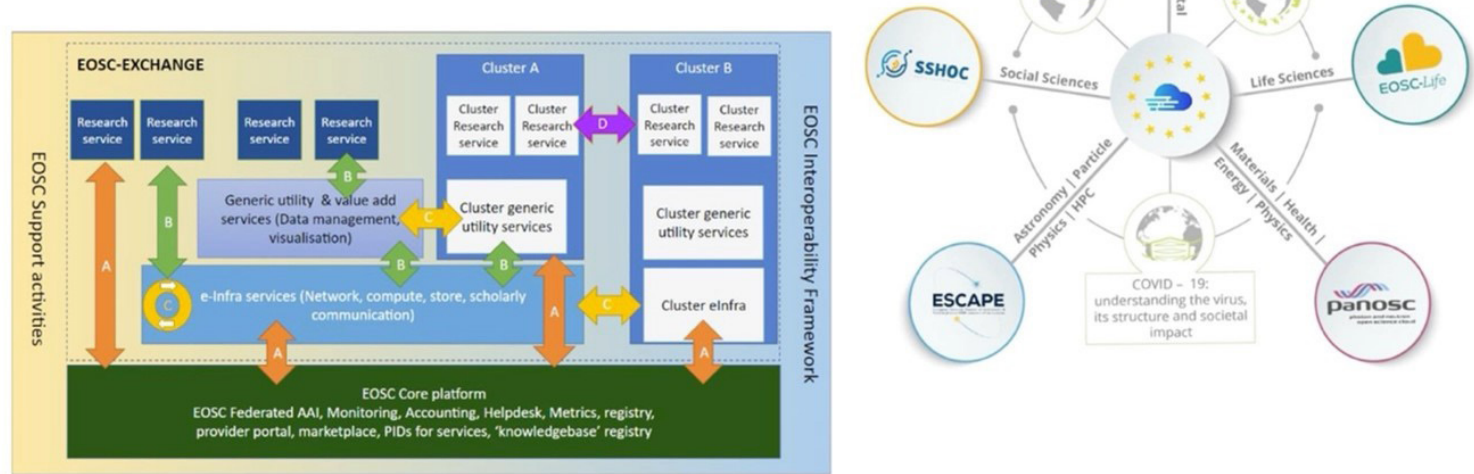

6.ábra: EOSC-Future projekt struktúrája

Az EOSC által is kiemelten kezelt Open Science nemzeti iniciatíváinak (open science cloud fejlesztéseknek és nemzeti és tudományterület EOSC „portálok” kialakításának, valamint FAIR elvet követő adat-infrastruktúra építéseknek) az összehangolására, a szolgáltatások integrálására törekvő projekthez kapcsolódó tényleges munkák elindultak. 2020 folyamán az RDA (a globális Research Data Alliance) magyarországi node-ja (HRDA) folytatta a munkáját - meetupokat tartott. HRDA-ban, melyben az alapító tagok között szerepel a KIFÜ is, képviselve az adat-infrastruktúrák hátterét biztosító hazai e-infrastruktúra fejlesztő és szolgáltató közösséget.

Az oktatási infrastruktúra és szolgáltatások fejlesztésének fontos projektje az Up2U 2020-ban befejeződött. Fő feladatként az európai partnerekkel együttműködésben a KIFÜ egy olyan oktatás támogatási eszközcsomagot fejlesztett ki, mely a közoktatás számára elérhetővé teszi és megújítja az NIIF Program szolgáltatásait.

Az előbb felsorolt projektek ugyanis - bár kevésbé voltak átütőek a nemzetközi kapcsolatok szempontjából, mint az említett "zászlóshajó" projektek, hozzájárultak a nemzetközi forrású hazai bevételek szerény növeléséhez, és ami még fontosabb, segítették szemléletünk és felkészültségünk gazdagítását. Egyrészt jelentős mértékben hozzájárultak a felfutóban lévő adat-infrastruktúra témakörbeli tapasztalataink bővítéséhez, másrészt egy valóban globális kitekintést tettek lehetővé. Eközben több fejlődő régió támogatásában vehettünk részt és a jövőt tekintve újabb ismeretekre tehettünk szert olyan térségekben, melyek egy része néhány év alatt ledolgozhatja hátrányát és kiváló együttműködési partner lehet a fejlesztéseinkben, itthon is és európai 
léptékben is. Érdemes itt megemlíteni az EAP és CAREN - a kelet-európai és középázsiai régiók e-infrastruktúra fejlesztéseinek támogatására irányuló - törekvéseket, melyekben szerény hozzájárulással ugyan, de amennyire módunk van rá, szintén igyekszünk fenntartani a közremüködésünket.

Ezt egészíti ki egy 2021 januárjában indult rurAllure ${ }^{8}$ projekt amelynek célja a kulturális együttműködés és a fenntartható turizmus elősegítése az európai történelmi zarándokútvonalak térségében. A célok eléréséhez a projekt korszerú informatikai megoldásokat alkalmaz a vidéki múzeumok és örökségi helyszínek népszerǔsítésére.

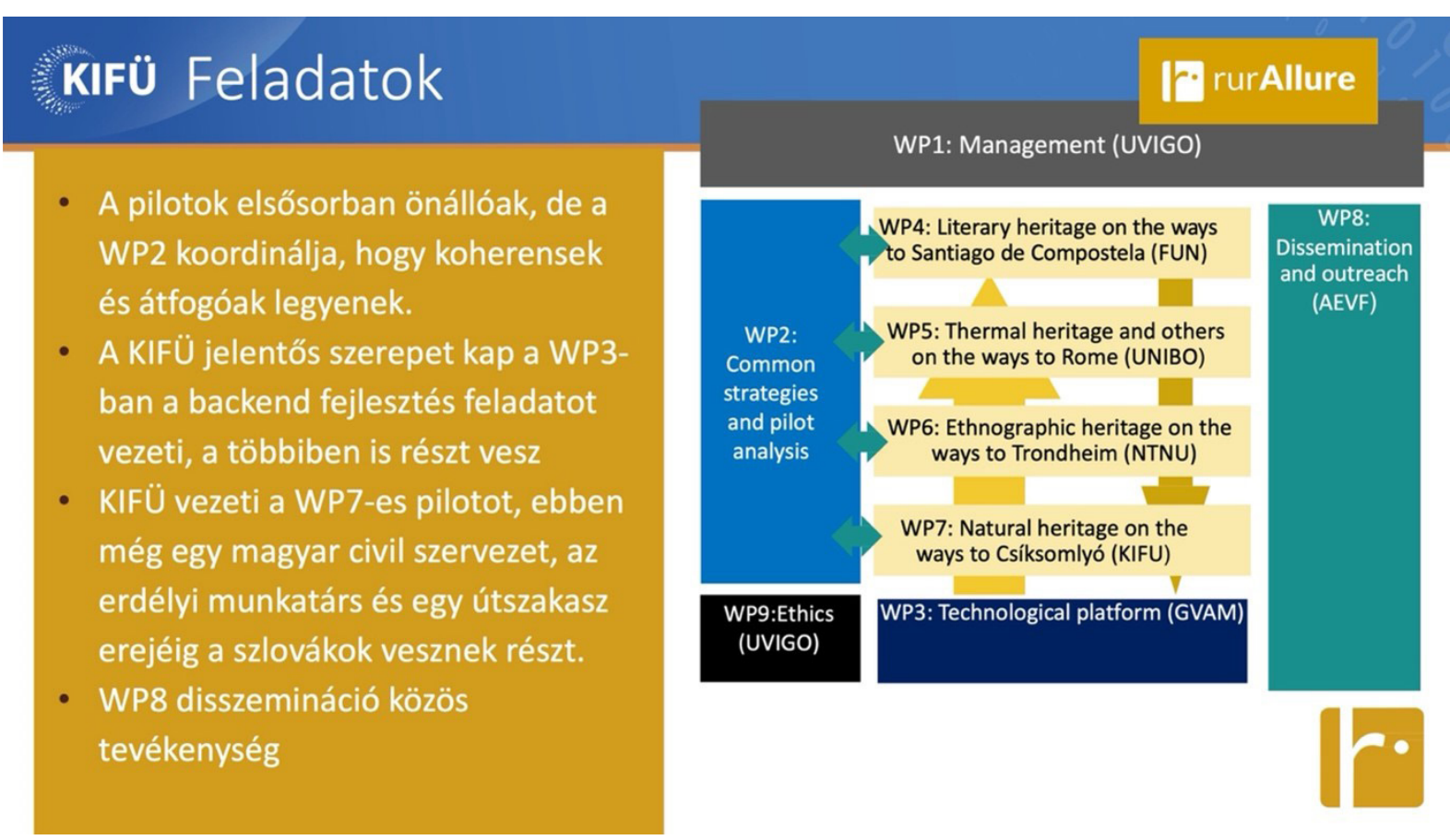

7.ábra: rurAllure projekt feladatai

\section{Összegzés}

Mint az előző években, a munkák most, 2020-at követően is folytatódnak, a feladatok bővülnek, az e-Infrastruktúra közösségek felelőssége nemzeti és nemzetközi szinten is egyre nő. A KIFÜ infrastruktúrája a GÉANT (az európai IKT infrastruktúra) valamint az EuroHPC és PRACE infrastruktúra (a szuperszámítástechnika európai infrastruktúrája) részeként, a multimédia információkezelés, az erőforrás és szolgáltatás-virtualizáció, a szövetségi azonosítás stb. eszközeire építve hatékony és teljes értékü kapcsolódást biztosít az európai kutatás összes intézményéhez és kutatójához, beleértve Európa valamennyi (ESFRI, ERIC és egyéb) kutatási infrastruktúráját is. Ezek a korábbiakban is említett 3 komponensú rendszer egyrészt garantálja a nemzetközi kompatibilitást, másrészt lehetőségeket teremt a versenyképes hazai kutatás számára a nemzetközi kutatásba való bekapcsolódásra. Ebben a soknemzetiségú kapcsolatrendszerben továbbra is fontos a hazai együttmúködés biztos alapokra épülő megszervezése és múködtetése, egyebek mellett az NIIF Program végrehajtásáért felelős KIFÜ, valamint a

8 https://rurallure.eu/ 
felhasználókat, a felhasználói közösséget tömörítő és annak igényeit közvetítő szakmai érdekvédelmi szervezet, a HUNGARNET Egyesület együttmúködésével, a közöttük kialakított és folyamatosan fejlesztendő kapcsolatból eredő lehetőségek kiaknázásával. 
(ㄷ) (1)

N

우 